\title{
AGE AND GROWTH OF THREE Odontesthes SPECIES FROM SOUTHERN BRAZIL (ATHERINOPSIDAE), WITH REFERENCE TO PHYLOGENETIC CONSTRAINTS IN THEIR LIFE-HISTORY
}

\author{
BECKER, F. G., ${ }^{1}$ BRUSCHI JR., W. ${ }^{1,2}$ and PERET, A. C. ${ }^{3}$ \\ ${ }^{1}$ Laboratório de Ecologia de Vertebrados, Departamento de Ecologia, Universidade Federal do Rio Grande do Sul, \\ Av. Bento Gonçalves, 9500, bloco 4, CEP 91501-970, Porto Alegre, RS, Brazil \\ ${ }^{2}$ BIOLAW Consultoria e Planejamento Ambiental, Rua José do Patrocínio, 548/201, \\ CEP 900-50002, Porto Alegre, RS, Brazil \\ ${ }^{3}$ Departamento de Hidrobiologia, Universidade Federal de São Carlos, C.P. 676, CEP 13565-905, \\ São Carlos, SP, Brazil \\ Correspondence to: Laboratório de Ictiologia, Museu de Ciências Naturais, Fundação Zoobotânica do Rio Grande \\ do Sul, Rua Salvador França, 1427, CEP 90690-000, Porto Alegre, RS, Brazil, \\ e-mail: fgb@fzb.rs.gov.br
}

Received August 2, 2002 - Aceepted February 18, 2002 - Distributed November 30, 2003

(With 1 figure)

\begin{abstract}
The age and growth of three silverside species are described, and a discussion on possible phylogenetic constraints on life-history characteristics is presented. Samples were collected monthly between March 1992 and February 1993 in three freshwater coastal lakes. Standard length-total length (Ls-Lt) and weight-length (Wt-Lt) relationships studied showed interspecific differences in comparisons between juveniles and adults, males and females. Age was determined by scales. The three species presented a life-cycle duration of 4 to 5 years, with growth coefficients values $(\mathrm{K})$ between 0.37 and 0.63 , and asymptotic lengths between 211 and $257 \mathrm{~mm}$. Some interspecific differences may be useful for distinguishing between species (sexual and life-stage related patterns in $\mathrm{L}_{\mathrm{s}}-\mathrm{L}_{\mathrm{t}}$ and $\mathrm{W}_{\mathrm{t}}-\mathrm{L}_{\mathrm{t}}$ ). The observed life-cycle ranges and maximum sizes were compared to those of other silversides and revealed a pattern coherent with available phylogenetic hypotheses at the supra-generic level, indicating that some lifehistory characteristics may be subject to phylogenetic constraints.
\end{abstract}

Key words: life history, phylogeny, age, growth, Atherinopsidae.

\section{RESUMO}

Idade e crescimento de três espécies de Odontesthes (Atherinopsidae) do sul do Brasil, com observações sobre a relação entre filogenia e história de vida de peixes-rei

Este estudo apresenta uma descrição das características de idade e crescimento de três espécies de Odontesthes, além de uma discussão sobre possíveis relações de características de história de vida com filogenia. Amostragens foram feitas mensalmente entre março/1992 e fevereiro/1993, em três lagoas costeiras do Rio Grande do Sul. As relações comprimento padrão-comprimento total (Ls-Lt) e peso-comprimento (Wt-Lt) revelaram diferenças interespecíficas nas comparações entre juvenis e adultos e entre machos e fêmeas. A idade foi determinada a partir das escamas. As três espécies apresentaram um ciclo de vida de 4 a 5 anos, com coeficientes de crescimento (K) entre 0,37 e 0,63 e comprimentos assintóticos entre 211 e $257 \mathrm{~mm}$. A duração do ciclo de vida e os tamanhos máximos foram comparados com aqueles de outras espécies de Atheriniformes e revelaram um padrão coerente com as hipóteses filogenéticas disponíveis em nível supragenérico, indicando que certas características de história de vida estão relacionadas ao contexto filogenético.

Palavras-chave: história de vida, filogenia, idade, crescimento, Atherinopsidae. 


\section{INTRODUCTION}

The explanation of biological problems can greatly benefit from the integration of phylogenetic hypotheses and behavioral and ecological studies (Miles \& Dunham, 1993). The case of the SouthAmerican silverside Odontesthes argentinensis (Atherinopsidae) is an example of the contribution of life-history characteristics to the study of taxonomic and evolutionary problems. This species was found to have a resident estuarine population morphometrically indistinguishable from the adjacent marine one (Bemvenuti, 1993). Nevertheless, both populations presented remarkable differences in genetic population structure and in reproductive biology and egg morphology characteristics (Beheregaray \& Levy, 2000). Similar situations seem to be common among other silversides. Both New World (Atherinopsidae) and Old World (Atherinidae) silversides (Dyer \& Chernoff, 1996; Dyer, 1998) present an overall uniformity in morphology and life history strategies, with many species forming isolated or semi-isolated populations (Bamber \& Henderson, 1988; Creech, 1992a, 1991; Beheregaray \& Levy, 2000). Because of this uniformity, interpopulational and interspecific differences were sought by means of genetic and morphometric techniques (Gajardo, 1987, 1988; Prodohl \& Levy, 1989; Gajardo, 1992; Creech, 1991, 1992a; Bemvenuti, 1997; Gallego et al., 1998; Beheregaray \& Levy, 2000). Differences in life cycle, age, and growth between populations and species have also been discussed (Prince \& Potter, 1983; Klink \& Eckmann, 1985; Potter et al., 1986; Bemvenuti, 1987; Becker, 1995; Scasso \& Campos, 1999).

Silversides are typical elements of the fish fauna in shallow coastal lakes of southern Brazil. Most silverside species in these lakes are included in the Odontesthes perugiae species group (family Atherinopsidae, according to Dyer, 1997). These coastal lakes have a recent geological history (Schwarzbold \& Schäfer, 1984) and form a complex system of either isolated or connected freshwater lakes associated with the estuarine system of the Tramandaí River. As is common for silversides, the Odontesthes species from these lakes are also very similar morphologically, being the outcome of rapid radiation associated with transgressive cycles of the Quaternary (Beheregaray, 2000; Behergaray et al., 2002). Several studies provide taxonomic, phylo- genetic, and evolutionary information about these species (Malabarba \& Dyer, 2002; Bemvenuti, 1997; Dyer, 1997, 1998; Beheregaray \& Sunnucks, 2000; Beheregaray \& Levy, 2000), and the life history of some populations has also been studied (Bemvenuti, 1987; Fialho \& Verani, 1994; Becker, 1995; Fialho, 1996; Fialho et al., 1996).

One of the main characteristics of fish life history is that very different growth patterns can be exhibited by the same species in different environments or by the same population in different years (Ricker, 1975; Wooton, 1990). Consequently, fish growth rates and absolute size seem not to be useful for distinguishing between species. Nevertheless, Wooton (1990) states that the success of programs of artificial selection based on growth traits suggests that spontaneous selection for these traits can occur in natural populations. Therefore, certain growth patterns may be potential indicators for taxonomic differentiation if they imply a more complex biological (and genetic) basis.

In this work, we describe the age and growth characteristics of three populations of silversides, each representing a different species of Odontesthes from freshwater coastal lakes of the Tramandaí River basin, southern Brazil. A brief discussion of the observed interspecific differences is also presented, as a preliminary attempt to assess the usefulness of life-history characteristics in taxonomic and phylogenetic studies.

\section{Study area}

The Tramandaí River basin is situated in northeastern Rio Grande do Sul, Brazil (approximately $29^{\circ} 45^{\prime}$ to $30^{\circ} 15^{\prime} \mathrm{S}, 50^{\circ} 00^{\prime}$ to $50^{\circ} 30^{\prime} \mathrm{W}$ ). The climate in the region is considered subtropical and humid. Rainfall is uniform throughout the year, although more intense and shorter in summer and less intense but longer in winter. The Tramandaí River basin comprises several isolated and connected shallow coastal lakes. The connected system is formed mostly by freshwater lakes, which are ecologically separated by the Tramandaí estuary into northern and southern freshwater sub-systems (see Schwarzbold \& Schäfer, 1984, for a further description). Odontesthes bicudo, O. piquava, and O. ledae are all freshwater species occurring, respectively, in the isolated lakes, northern interconnected lakes, and southern interconnected lakes. 


\section{MATERIAL AND METHODS}

\section{Data collection}

The three species studied in the present work (O. bicudo, O. piquava, and O. ledae, Malabarba $\&$ Dyer, 2002) belong to the $O$. perugiae species group (Dyer, 1998) and are freshwater forms with non-overlapping geographical distributions in the Tramandaí River system, except for the populations of $O$. bicudo and $O$. piquava from Lake Caconde. These three species have also been recognized by Beheregaray (2000) and Beheregaray et al. (2002) using mtDNA sequences.

Between March 1992 and February 1993, samples were taken monthly using gill nets with mesh sizes of 1.2 and $1.5 \mathrm{~cm}$ (bar measure) and a seine net of $16 \mathrm{~m} \times 3 \mathrm{~m}$ (mesh size of $0.3 \mathrm{~cm}$ ). Samples of $O$. bicudo were further collected until May 1994. Three lakes were sampled: Lake Caconde, Lake Pinguela, and Lake Rondinha, representing the geographical range of $O$. bicudo, O. piquava, and O. ledae, respectively.

Captured fish were stored in ice for posterior examination and scale collection. Data on total length $\left(\mathrm{L}_{\mathrm{f}}\right)$, standard length $\left(\mathrm{L}_{\mathrm{s}}\right)$, total weight $\left(\mathrm{W}_{\mathrm{t}}\right)$, and sex of each individual were obtained. Scales collected from sub-samples of approximately 10 individuals from each $20 \mathrm{~mm}$ length class were taken from the left side of the body and preserved in 70\% ethanol. In order to assess which part of the body provides better scales for determining aging, samples from three different regions were taken: posteriorly to the pectoral fin base, from a dorso-lateral area below the dorsal fin, and from a ventro-lateral area below the dorsal fin. No remarkable differences were noted among scales from the three areas. However, scales from the mid-body lateral area were of a more uniform size than those collected near the pectoral fin, and were thus preferred for analysis. With scales immersed in $70 \%$ ethanol, rings were counted under a stereomicroscope. This method was judged to be better after trials with scales mounted on slides, immersed in water, or stained with alizarin red using a modificaton of the Dingerkus \& Uhler (1977) technique.

Scales of all three Odontesthes species were thin and difficult to read. Exhaustive adjustments with incident light and under illumination were necessary to identify the annual rings. Ring identification and counting was done in two stages, the second of which started only after all scales from the three species had been examined. During the reading process, the length and sex of the fish were not known by the reader. Scales in which the rings were too difficult to distinguish were eliminated from the study, which resulted in a decreased sample size and the need for pooling monthly data into threemonth periods, each corresponding to one season of the year.

\section{Data analysis}

The weight-length relationship, $\mathrm{W}_{\mathrm{t}}=\mathrm{aL}_{\mathrm{t}}^{\mathrm{b}}$, was estimated by least-squares regression of the logarithmically transformed weight-length data. The slopes of the regressions (parameter $b$ ) of the logtransformed values of $\mathrm{W}_{\mathrm{t}}$ and $\mathrm{L}_{\mathrm{t}}$ were tested for allometry (Ho: $b=3$ ) using the t-test described in Zar (1999). Statistical differences of $b$ between juveniles and adults of each species were tested according to the t-test described in Zar (1999). An analysis of covariance (ANCOVA) was used to compare the regression parameters among females of the three species; the same procedure was repeated for males. The multi-comparison Tukey test was employed to detect pairwise contrasts if the ANCOVA revealed significant differences. The same statistical tests were used for comparisons of the standard length-total length relationships, except that the null hypothesis for allometry was $b=1$ (Gould, 1966). The $\mathrm{L}_{\mathrm{s}}-\mathrm{L}_{\mathrm{t}}$ relationships were estimated by least-squares regression on the original $\mathrm{L}_{\mathrm{s}}-\mathrm{L}_{\mathrm{t}}$ values.

The time of annual ring formation was determined by following the seasonal variation of the mean total length that corresponded to a given number of scale rings. It was assumed that ring formation occurred whenever the mean length for a given ring count decreased between two consecutive seasons (Vazzoler, 1981).

Length growth curves were determined according to the von Bertalanffy model, after the Ford-Walford transformation, and considering $\mathrm{t}_{\mathrm{o}}=$ 0 . Age at the time of first ring formation was determined according to Santos (1978). Because of low sample size, male and female data were pooled to estimate the $O$. ledae growth curves.

\section{RESULTS}

\section{Weight-length relationship $\left(W_{t}=a L_{t}^{b}\right)$}

The weight-length relationships were estimated separately for adult (males and females; Table 1) and young specimens (individuals with gonads not yet 
developed; Table 2). For O. bicudo, separate estimations were also made to compare results between two consecutive years (1993 and 1994).

In adults, allometry, meaning that larger individuals are relatively more elongated than smaller ones, was observed only in O. piquava ( $\mathrm{p}<0.05$ ). Juveniles of the three species presented isometric $\mathrm{W}_{\mathrm{t}}-\mathrm{L}_{\mathrm{t}}$ relationships. In juveniles of the three species, and in adults of $O$. bicudo and $O$. ledae, the body proportions remained comparatively the same in both smaller and larger individuals (isometry).

Intraspecific comparisons between males and females showed that the estimated $b$ values were significantly different in $O$. bicudo ( $\mathrm{p}<0.05)$. Neither $O$. piquava nor $O$. ledae presented sexual differences in the $\mathrm{W}_{\mathrm{t}}-\mathrm{L}_{\mathrm{t}}$ relationship.

Intraspecific comparisons between adults and juveniles (Table 2) revealed significant differences in the three species (except between juveniles and female $O$. bicudo; Table 2), indicating that juveniles tend to have different $\mathrm{W}_{\mathrm{t}}-\mathrm{L}_{\mathrm{t}}$ relationships than adults. The calculated $t$ values for significant intraspecific differences of $b$ between juveniles and adults were: $O$. bicudo males $\mathrm{t}_{0.05(2), 679}=3.39 ; O$. piquava males $\mathrm{t}_{0.05(2), 1073}=4.82$, and females $\mathrm{t}_{0.05(2), 1466}=6.73$; and $O$. ledae males $\mathrm{t}_{0.05(2), 1615}=5.39$ and females $\mathrm{t}_{0.05}$ (2), $1232=3.67$ ).

Interspecific comparisons using ANCOVA revealed no significant differences in parameter $b$. However, differences in parameter $a$ were significant for both females $(\mathrm{p}<0.05)$ and males $(\mathrm{p}<0.05)$. The Tukey test showed that the three species had different $a$ values ( $a_{\text {O. bicudo }} \neq a_{\text {o. piquava }} \neq a_{\text {O. ledae }}$; males and females analyzed separately).

The comparison between the 1992 and 1993 samples of $O$. bicudo showed no significant difference for both parameters $a$ and $b$, therefore the data was pooled and a single weight-length relationship was calculated for the species (Table 1). In all cases (1992 sample, 1993 sample, and pooled sample), $b$ was significantly different between males and females, and growth was isometric.

Total length-standard length regressions $\left(L_{s}=a+\right.$ bL)

The parameters of the $\mathrm{L}_{\mathrm{s}}-\mathrm{L}_{\mathrm{t}}$ relationships are presented in Table 3. In all species, relative growth is isometric ( $b$ not significantly different from 1 ). The ANCOVA indicated significant interspecific differences in parameter $b$ among females and among males ( $\mathrm{p}<0.05 ; \mathrm{F}_{\text {females (2), } 1553}=14.23, \mathrm{M}_{\text {males (2), } 1462}=$ 12.53). The Tukey test for males indicated that $b_{\text {O. bicudo }} \neq b_{\text {O. piquava }}=b_{\text {O. ledae }}$. For females, the test indicated that $b_{\text {o. bicudo }} \neq b_{\text {O. piquava }}$, but $b_{\text {O. ledae }}$ could not be unambiguously differentiated from either $b_{\text {O. bicudo }}$ or $b_{\text {O. piquava }}$.

\section{Age and growth}

The consistency of scale readings is indicated by the low \% coefficient of variation of total individual length $\left(\mathrm{L}_{\mathrm{t}}\right)$ in relation to ring counts in the three studied species (Table 4). Annual ring formation takes place between winter and spring for $O$. bicudo (males and females) and for female $O$. piquava. In male $O$. piquava and in $O$. ledae, annual rings are formed between spring and summer (Fig. 1).

The age of first annual ring formation was different in the three studied species (Table 5). In O. bicudo, the first ring is formed when the males are about one year old and females are about two years old, while in O. piquava the first annual ring forms when both females and males are about two years old (Table 5). In O. ledae (pooled female and male data) the estimated age of first ring formation was 1.5 year.

Up to three annual rings were observed in females and males of the three studied species. Consequently, it can be inferred that the population of $O$. bicudo was structured in to 4 and 5 age classes (males and females, respectively). The populations of $O$. piquava and $O$. ledae had 5 and 4 age classes, respectively. The estimated lengths at each age class, as calculated from the von Bertalanffy growth equation (Table 5), indicate that $O$. bicudo and $O$. ledae grow faster than $O$. piquava (see also Table 5). O. bicudo lives longer and reaches larger sizes than $O$. ledae.

The growth coefficient was lower for females (sexual differences were not analyzed for $O$. ledae). Growth in the first year, indicated by the proportion of asymptotic length $\left(\mathrm{L}_{\mathrm{t} 8}\right)$ attained at the first year of life, was approximately similar for the three species (Table 5). 

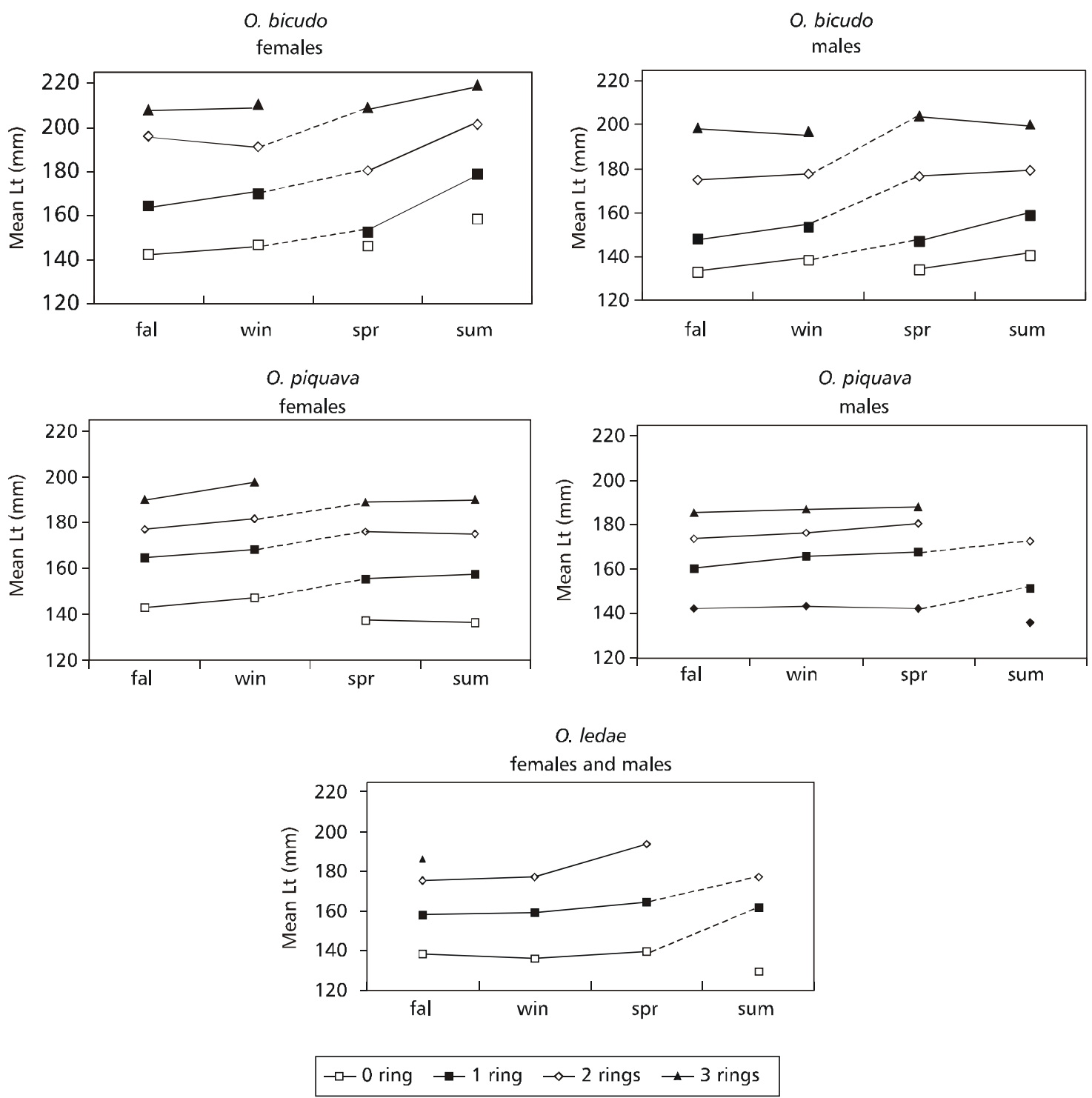

Fig. 1 - Seasonal variation of mean $\mathrm{L}_{\mathrm{t}}$ in relation to the number of scale rings. The coefficient of variation of $\mathrm{L}_{\mathrm{t}}$ according to number of rings was under $17 \%$ in all three species. Dashed lines indicate time of ring formation; fal $=$ fall, win $=$ winter, spr $=$ spring, sum $=$ summer. 
TABLE 1

Weight-length regressions $\left(\ln \mathrm{W}_{\mathrm{t}}=\ln a+b \ln \mathrm{L}_{\mathrm{t}}\right)$ for adults of three freshwater Odontesthes species from southern Brazil.

\begin{tabular}{|l|c|c|c|c|c|c|c|c|}
\hline & $\mathbf{s e x}$ & $\mathbf{l n} \boldsymbol{a}$ & $\mathbf{S E} \boldsymbol{a}$ & $\boldsymbol{b}$ & $\mathbf{S E} \boldsymbol{b}$ & $\mathbf{n}$ & $\mathbf{L}_{\mathbf{t}(\mathbf{m i n})}-\mathbf{L}_{\mathbf{t}(\mathbf{m a x})}$ & $\mathbf{r}^{\mathbf{2}}$ \\
\hline \multirow{2}{*}{ O. bicudo (total) } & $\mathrm{m}$ & -11.378 & 0.103 & 2.885 & 0.020 & 2075 & $120-212$ & 0.91 \\
\cline { 2 - 9 } & $\mathrm{f}$ & -11.882 & 0.114 & 2.982 & 0.022 & 1341 & $120-253$ & 0.93 \\
\hline \multirow{2}{*}{ O. bicudo (1993) } & $\mathrm{m}$ & -11.264 & 0.123 & 2.860 & 0.024 & 1537 & $120-208$ & 0.90 \\
\cline { 2 - 9 } & $\mathrm{f}$ & -12.040 & 0.146 & 3.008 & 0.029 & 714 & $121-253$ & 0.94 \\
\hline \multirow{2}{*}{ O. bicudo (1992) } & $\mathrm{m}$ & -11.240 & 0.180 & 2.864 & 0.036 & 538 & $120-212$ & 0.92 \\
\cline { 2 - 9 } & $\mathrm{f}$ & -11.772 & 0.167 & 2.966 & 0.033 & 627 & $120-238$ & 0.93 \\
\hline \multirow{2}{*}{ O. piquava } & $\mathrm{m}$ & -11.149 & 0.170 & $2.842^{*}$ & 0.034 & 655 & $120-194$ & 0.92 \\
\cline { 2 - 9 } & $\mathrm{f}$ & -11.101 & 0.234 & $2.843^{*}$ & 0.046 & 262 & $120-200$ & 0.94 \\
\hline \multirow{2}{*}{ O. ledae } & $\mathrm{m}$ & -11.435 & 0.202 & 2.908 & 0.040 & 288 & $120-192$ & 0.95 \\
\cline { 2 - 9 } & $\mathrm{f}$ & -11.598 & 0.149 & 2.949 & 0.030 & 671 & $120-194$ & 0.94 \\
\hline
\end{tabular}

* Statistically different from $3(\mathrm{p}<0.05)$.

TABLE 2

Weight-length regressions $\left(\ln \mathrm{W}_{t}=\ln a+b \ln \mathrm{L}_{t}\right)$, for juveniles of three freshwater Odontesthes species from southern Brazil. The regression coefficient $b$ is not statistically different from 3 (isometric growth) in the three species.

\begin{tabular}{|l|c|c|c|c|c|c|c|}
\hline & $\ln \boldsymbol{a}$ & $\mathbf{S E} \boldsymbol{a}$ & $\mathbf{B}$ & $\mathbf{S E} \boldsymbol{b}$ & $\mathbf{N}$ & $\mathbf{L}_{\mathbf{t}(\mathbf{m i n})}-\mathbf{L}_{\mathbf{t}(\mathbf{m a x})}$ & $\mathbf{r}^{\mathbf{2}}$ \\
\hline O. bicudo & -12.208 & 0.108 & $3.03^{1}$ & 0.03 & 145 & $18-116$ & 0.99 \\
\hline O. piquava & -12.767 & 0.051 & $3.17^{2}$ & 0.01 & 815 & $18-99$ & 0.98 \\
\hline O. ledae & -12.765 & 0.038 & $3.17^{2}$ & 0.01 & 948 & $20-116$ & 0.99 \\
\hline
\end{tabular}

${ }^{1}$ Not significantly different from female adults; ${ }^{2}$ significantly different from both male and female adults $(\mathrm{p}<0.05)$.

TABLE 3

Standard length - total length linear regressions $\left(\mathrm{L}_{\mathrm{s}}=a+b \mathrm{~L}_{\mathrm{t}}\right)$ for three freshwater Odontesthes species from southern Brazil. Values of parameter $b$ were not significantly different from $1(p<0.05) ; m=$ males; $f=$ females; $S E=$ standard error; $n=$ sample size.

\begin{tabular}{|l|c|c|c|c|c|c|c|c|}
\hline & $\mathbf{s e x}$ & $\boldsymbol{a}$ & $\mathbf{S E} \boldsymbol{a}$ & $\boldsymbol{b}$ & $\mathbf{S E} \boldsymbol{b}$ & $\mathbf{N}$ & $\mathbf{L}_{\mathbf{t ( m i n})}-\mathbf{L}_{\mathbf{t}(\mathbf{m a x})}$ & $\mathbf{r}^{\mathbf{2}}$ \\
\hline \multirow{2}{*}{ O. bicudo } & $\mathrm{m}$ & -3.134 & 0.533 & 0.866 & 0.003 & 522 & $120-204$ & 0.99 \\
\cline { 2 - 9 } & $\mathrm{f}$ & -3.178 & 0.452 & 0.867 & 0.003 & 626 & $120-238$ & 0.99 \\
\hline \multirow{3}{*}{ O. piquava } & $\mathrm{m}$ & -1.396 & 0.543 & 0.849 & 0.004 & 656 & $120-194$ & 0.99 \\
\cline { 2 - 9 } & $\mathrm{f}$ & -2.208 & 0.812 & 0.856 & 0.005 & 262 & $121-200$ & 0.99 \\
\hline \multirow{2}{*}{ O. ledae } & $\mathrm{m}$ & 0.554 & 0.723 & 0.838 & 0.005 & 288 & $120-192$ & 0.99 \\
\cline { 2 - 9 } & $\mathrm{f}$ & 0.024 & 0.496 & 0.845 & 0.003 & 671 & $120-194$ & 0.99 \\
\hline
\end{tabular}


TABLE 4

Mean and \% coefficient of variation of total length $\left(L_{t}\right)$ in relation to number of age rings in scales of three Odontesthes species from southern Brazil.

\begin{tabular}{|c|c|c|c|c|c|c|c|c|c|c|}
\hline \multicolumn{3}{|c|}{ O. bicudo } & \multicolumn{4}{c|}{ O.piquava } & \multicolumn{4}{c|}{ O. ledae } \\
\hline \multicolumn{3}{|c|}{ males } & \multicolumn{2}{c|}{ females } & \multicolumn{2}{c|}{ males } & \multicolumn{3}{c|}{ females } \\
\hline rings & Mean Lt & CV\% & Mean Lt & CV\% & Mean Lt & CV\% & Mean Lt & CV\% & Mean Lt & CV\% \\
\hline 0 & 136.2 & 7.6 & 147.4 & 9.5 & 141.4 & 7.7 & 141.0 & 9.0 & 135.5 & 8.9 \\
\hline 1 & 150.9 & 7.8 & 167.7 & 10.0 & 159.8 & 6.0 & 162.3 & 6.0 & 160.2 & 5.3 \\
\hline 2 & 176.9 & 4.9 & 192.3 & 6.7 & 175.2 & 3.4 & 177.0 & 4.8 & 176.4 & 5.3 \\
\hline 3 & 199.6 & 1.5 & 210.2 & 7.1 & 186.3 & 3.0 & 192.3 & 2.5 & 186.5 & 0.4 \\
\hline
\end{tabular}

TABLE 5

Approximate size $\left(\mathrm{L}_{\mathrm{t}}\right.$, in $\left.\mathrm{mm}\right)$ at age (years) for each Odontesthes species, calculated according to the estimated parameters of the von Bertallanfy growth model.

\begin{tabular}{|c|c|c|c|c|c|}
\hline \multicolumn{3}{|c|}{ O. bicudo } & \multicolumn{2}{c|}{ O. piquava } & O. ledae \\
\hline age (years) & females & males & females & males & $\begin{array}{c}\text { females + } \\
\text { males }\end{array}$ \\
\hline 1 & 80 & 102 & 76 & 78 & 97 \\
\hline 2 & 135 & 156 & 126 & 127 & 150 \\
\hline 3 & 173 & 185 & 159 & 158 & 179 \\
\hline 4 & 200 & 201 & 180 & 177 & 195 \\
\hline 5 & 217 & - & 194 & 189 & - \\
\hline
\end{tabular}

\section{DISCUSSION}

\section{Standard length-total length and weight-length relationships}

The $\mathrm{L}_{\mathrm{s}}-\mathrm{L}_{\mathrm{t}}$ relationships are usually calculated because many studies employ standard length instead of total length or because, in some situations, the total length of a fish cannot be measured, therefore $L_{t}$ is estimated from $\mathrm{L}_{\mathrm{s}}$. Similar arguments are valid regarding the weight-length relationships which, in addition, are needed for studying the condition of the fish (Le Cren, 1951). These morphometric relationships may well provide information about interspecific or interpopulational variation, if statistical differences are detected. The parameter "b" of equations describing linear morphometric relationships can be used for comparing samples in two ways. First, significant differences between the values estimated for each sample can be tested. Second, the type of change in a body dimension relative to the size of the body (allometry or isometry) can be compared between samples. The parameter $b$ of the equation $\ln \mathrm{W}_{\mathrm{t}}=\ln a+$ $b \mathrm{~L}$ is a descriptor of change in relative proportions with size. When $b=3$, body proportions do not change with size (isometry). However, when $b>3$ or $b<3$, body proportions change with size (allometry). The detection of isometry or allometry using bivariate analysis can also represent taxonomic information (Gould, 1966; Sweet, 1980; Wilhelm, 1984).

Regarding $\mathrm{W}_{\mathrm{t}}-\mathrm{L}_{\mathrm{t}}$ relationships, juveniles of the three species presented significantly different $b$ values. Both juvenile and adults presented the same type of relative change in body proportions (isometry), except for those of $O$. piquava. In this species, body proportions change differently in juveniles and adults (the relationship is isometric in juveniles and negative allometric in adults), so that the ratio of $\mathrm{W}_{\mathrm{t}}$ relative to $\mathrm{L}_{\mathrm{t}}$ changes with size in adults, but not in juveniles. Interspecific comparisons of the $\mathrm{L}_{\mathrm{s}}-\mathrm{L}_{\mathrm{t}}$ and $\mathrm{W}_{\mathrm{t}}$ $\mathrm{L}_{\mathrm{t}}$ relationships showed differences for parameter $a$, 
but not for parameter $b$. When two species have the same $b$ in the $\mathrm{W}_{\mathrm{t}}-\mathrm{L}_{\mathrm{t}}$ relationship, the one with larger value for $a$ will tend to be heavier for a given $\mathrm{L}_{t}$. The comparisons of the estimated $a$ values indicate that males and females of $O$. piquava tend to be heavier than males and females of $O$. bicudo and $O$. ledae of a given length. $O$. ledae tends to have the lightest males and $O$. bicudo, the lightest females.

Similarly, when two species have the same $b$ in the $\mathrm{L}_{\mathrm{s}}-\mathrm{L}_{\mathrm{t}}$ relationship, the species with higher $a$ will, at the same $\mathrm{L}_{\mathrm{t}}$, have a comparatively larger standard length than a species with lower $a$. Total length can be indirectly calculated as $\mathrm{L}_{\mathrm{t}}=\mathrm{L}_{\mathrm{s}}+\mathrm{L}_{\mathrm{c}}$ (where $\mathrm{L}_{\mathrm{c}}$ is caudal fin length). Thus, species with higher $a$ will also have a shorter caudal length. Among the studied species, both female and male specimens of $O$. bicudo tend to have longer standard lengths and shorter caudal fins. The relation between size of caudal fin length and body length has been related to fish locomotion and foraging strategies (Webb, 1984), although not at the level of the subtle morphometric variations here observed. Such relation between form and function suggests that differences in $\mathrm{L}_{\mathrm{s}}-\mathrm{L}_{\mathrm{t}}$ may indicate underlying ecomorphological distinctiveness among the studied species. In fact, the three species present different feeding habits, with $O$. bicudo eating mainly fish, $O$. piquava preying on allochthonous insects, and $O$. ledae on zooplankton (C. B. Fialho, personal communication).

The $b$ parameter of $\mathrm{W}_{\mathrm{t}}-\mathrm{L}_{\mathrm{t}}$ relationships is known to vary between populations or within the same population (seasonally, between sexes and between life stages, Bagenal \& Tesch, 1978). Nevertheless, when found to be relatively constant within a population or species, it can be used for differentiation of small taxonomical units like any other morphometric relationship (Le Cren, 1951). In the present work, the results about interspecific comparisons of the $\mathrm{W}_{\mathrm{t}}-\mathrm{L}_{\mathrm{t}}$ parameters provided evidence of differences between the three studied species only for parameter $a$. These differences should not be taken as taxonomically important because the $a$ values estimated may change with annual variations in the environmental conditions (e.g., food availability).

On the other hand, some differences observed in the $\mathrm{L}_{\mathrm{s}}-\mathrm{L}_{\mathrm{t}}$ and $\mathrm{W}_{\mathrm{t}}-\mathrm{L}_{\mathrm{t}}$ relationships (related to sexual dimorphism, juvenile vs. adult differences in $b$ and allometry) may yield taxonomical meaning for the Odontesthes species studied. These should not be considered as separate, well-defined characters, but as a set of characteristics jointly indicating that the observed differences could represent interspecific distinctiveness.

There are four relevant aspects regarding $\mathrm{L}_{\mathrm{s}}-$ $\mathrm{L}_{\mathrm{t}}$ and $\mathrm{W}_{\mathrm{t}}-\mathrm{L}_{\mathrm{t}}$ relationships observed in this study. First, the three species presented significant differences in $\mathrm{L}_{\mathrm{s}}-\mathrm{L}_{\mathrm{t}}$, which may indicate subtle differences in locomotion and foraging. Second, O. piquava was the only species where juveniles and adults presented different types of relative growth in $\mathrm{W}_{\mathrm{t}}-\mathrm{L}_{\mathrm{t}}$ relationships (isometry in juveniles, negative allometry in adults), suggesting that, in contrast with other species, $O$. piquava presents a pattern of variation in relative body proportions that varies with size in adults but not in juveniles. Third, significant differences between female and male $\mathrm{W}_{\mathrm{t}}-\mathrm{L}_{\mathrm{t}}$ occurred only in $O$. bicudo, suggesting sexual dimorphism in growth pattern in this species but not in the others. Finally, juveniles had different $\mathrm{W}_{\mathrm{t}}-\mathrm{L}_{\mathrm{t}}$ relationships ( $b$ values) from adults in all species, except for female $O$. bicudo. This suggests a particular life-stage related modification of the $\mathrm{W}_{\mathrm{t}}-\mathrm{L}_{\mathrm{t}}$ in this species.

\section{Age and growth}

Accuracy and precision assessments are important in age determination studies, particularly when results are intended for use in fisheries management (Campana, 2001). Scales of Odontesthes were difficult to read, but in those that were readable, ring counts of individuals of a given size were consistent, providing a measure of precision. Although precision (the reproducibility of repeated measurements on a given structure) cannot be used as an indicator of accuracy (the closeness of the age estimate to the true value), it is valuable for assessing the relative ease of determining age of a particular structure or of the reproducibility of an individual's age determinations (Campana, 2001). Accuracy was not checked in the present study, and its results should be applied with caution in stock assessment. However, the relative precision found allows for comparison of general patterns in the life histories of the studied species.

Among the species studied, O. bicudo is the one that lives longest and $O$. ledae is the one that lives least, and this is reflected in the maximum total length observed for each species. The comparison between the populations of $O$. bicudo from Lake Caconde and Lake Emboaba (Fialho, 1992) shows generally concordant age and growth characteristics, in spite of the different sampling periods and lack of separate estimates of male and female growth in 
the later population. The asymptotic length in the Emboaba population was $218 \mathrm{~mm}$, and 218 and 256 $\mathrm{mm}$ in Lake Caconde. The size of males at any age class was always larger in Lake Caconde than in Lake Emboaba, suggesting that growth is faster in the first. For females up to three years old, growth is equivalent in both populations, but after that, growth is faster in Lake Caconde. The faster growth in that population could be a consequence of improved food supply, as primary productivity is higher than in Lake Emboaba. Similarly to the Lake Caconde population, in that of Lake Emboaba (Fialho, 1992), the first annual ring is formed when individuals are 1.5 year old, and the life-cycle duration is about 5 years.

Annual rings of scales and otoliths are usually formed in a particular season of the year, reflecting the effects of exogenous (environmental) and endogenous (genetic) factors (Nikolsky, 1963; Wootton, 1990). In temperate regions, the formation of annual rings is generally linked to the marked seasonality, particularly to low temperatures and a short photoperiod in winter (Bagenal \& Tesch, 1978). In many tropical species, formation of annual rings is related to reproduction more than to a specific season of the year, possibly because temperature changes and photoperiod variations are subtler than in high latitudes. As a result, reproduction would demand a reallocation of energy that otherwise would be used in somatic growth. However, reproduction of tropical fish usually coincides with other events of marked environmental seasonality, such as flooding periods (Lowe-McConnell, 1987; Vazzoler et al., 1997), and it is possible that tropical species are sensitive to even more subtle environmental fluctuations (Lowe-McConnell, 1987).

Although annual ring formation was found to coincide with reproduction in some silversides (Sverlij \& Arceredillo, 1991; Creech, 1992b), in both Atherinidae and Atherinopsidae slow growth is usually correlated to winter (Markevich, 1977; Vila et al., 1981; Palmer \& Culley, 1983; Villavicencio \& Muck, 1984; Klink \& Eckmann, 1985; Fernandez-Delgado et al., 1988; Elías et al., 1991; Leonardos \& Sinis, 2000). However, the reproductive season of many silversides starts in winter, particularly in the South American Atherinopsidae (Moreno et al., 1977; Bemvenuti, 1987; Villavicencio \& Muck, 1984; Vila et al., 1981), so that it is difficult to determine the relative importance of winter or reproduction on annual ring formation.

Environmental seasonality in the lakes of the Tramandaí River basin is most evidently reflected by water temperature. Monthly variation of water temperature in Lake Caconde between summer and winter can be as much as $20^{\circ} \mathrm{C}$ (approximately 13 to $25^{\circ} \mathrm{C}$ ). Water level fluctuation is also seasonal, but not as markedly as temperature.

The relationship between annual ring formation, winter, and reproduction was assessed using the information about reproductive cycle in Becker (1995). In $O$. bicudo, ring formation coincided with the process of final gonadal maturation and the spawning peak (between winter and spring). In the $O$. bicudo population of Lake Emboaba (Fialho, 1992), ring formation occurred approximately under the same conditions, but between fall and winter. In O. piquava, growth ring formation in females took place between winter and spring, and reproduction occurred by the end of winter and early spring. In males, ring formation took place between spring and summer, after the end of the reproductive season but coinciding with the lowest mean condition of the study period. No biological explanation could be found for this difference between females and males, and it is possibly a result of error in interpretation or in aging determination method, indicating that accuracy (Campana, 2001) of this result should be checked in further studies.

In $O$. ledae, ring formation occurred between spring and summer, after the end of the reproductive period. Consequently, the studied species presented an ambiguous relationship between ring formation, winter, and reproduction, as observed in other South American silversides.

\section{Life history and systematics of silversides}

The estimated lifetime growth (the $\mathrm{K}$ coefficient of the von Bertalanffy growth model) and first year percentage of asymptotic growth for the three Odontesthes species studied are within range of observed values for other South American silversides. Maximum and minimum $\mathrm{K}$ values were respectively observed in male Basilichthys australis ( $\mathrm{K}=0.78$, Vila et al., 1981) and $O$. bonariensis $(\mathrm{K}=$ 0.09; Vila \& Soto, 1986). This is also true for growth during the first year, which was faster in male $B$. australis (67\% of $\mathrm{L}_{t}$; Vila et al., 1981) and slower in O. bonariensis (11\% of $\mathrm{L}_{\mathrm{t}}$; Vila \& Soto, 1986). Considering the available data for South American silversides, it has not been possible to discern any pattern in age and growth relative to latitude, geographic proximity of species or type of habitat (marine $\mathrm{x}$ freshwater). The results of studies on different $O$. bonariensis populations (Burbidge $e t$ 
al., 1974; Freyre, 1976; Vila \& Soto, 1986; Sverlij \& Arceredillo, 1991) suggest that age and growth characteristics in Odontesthes are highly dependent on environmental conditions. For the above reasons, and because growth parameters and age structure are known to vary among populations in many other species (Bagenal \& Tesch, 1978; Wootton, 1990), these characteristics are not adequate for taxonomical purposes. Consistent comparative analysis is also precluded by the diversity of aging determination methods employed in different studies, and the lack of data on more than one population of each species.

Nevertheless, patterns that are more general were apparent from comparisons with species of Atherinidae and within Atherinopsidae subfamilies. The family Atherinopsidae comprises the subfamilies Menidiinae and Atherinopsinae, the later with two tribes, Atherinopsini and Sorgentinini. Most South American silversides are included in the Sorgentinini (Dyer, 1998). Sorgentinin silversides present some common life history characteristics that distinguish them from the majority of other members of the family and from most Atherinidae. The Sorgentinini typically present a long life-cycle, ranging from 3 to 10 years, and maximum total lengths between 150 and $750 \mathrm{~mm}$ (Ciechomski, 1972; Burbidge et al., 1974; Freyre, 1976; Vila et al., 1981; Villavicencio \& Muck, 1984; Klink \& Eckmann, 1985; Vila \& Soto, 1986; Bemvenuti, 1987; Elías et al., 1991; Fialho, 1992). The life-cycles of other Atherinopsidae (subfamily Menidiinae and tribe Atherinopsini) and of the Atherinidae seldom extend 3 years, and individuals rarely attain more than $120 \mathrm{~mm}$ in length (see Turnpenny et al., 1981; Hubbs, 1982; Milton \& Arthington, 1983; Palmer \& Culley, 1983; Prince \& Potter, 1983; Conover, 1985; Potter et al., 1986; Warkentine \& Rachlin, 1987; Creech, 1992b).

There are exceptions to the above generalization: certain Chirostoma (Menidiinae), a genus endemic to the Mexican Plateau, can attain up to 300 $\mathrm{mm}$ in length and reach 4 years of age (Barbour, 1973; Jimenez-Badillo \& Gracia, 1995; Aguilar \& Navarrete, 1997). The only short-lived, small silversides in South America are the Atherinella species (Menidiinae; Bemvenuti, 1987; Paiva-Filho \& Giannini, 1990; Unger \& Lewis, 1991). Atherina mochon, which reaches about $140 \mathrm{~mm}$ in length and lives up to 5 years, was the only atherinid found to live longer than 3 years (Markevich, 1977). Some atherinids may reach sizes between 150 and $189 \mathrm{~mm}$, but their life cycle is not longer than 2 years (Prince
\& Potter, 1983; Potter et al., 1986; Creech, 1992b; Conand, 1993). Lahille (1929, apud Prince \& Potter, 1983) and Elías et al. (1991) have previously commented on these patterns in the life cycles of silversides, but not in a phylogenetic context. Presently, the coherence of the described patterns with available phylogenetic hypotheses for silversides (Dyer \& Chernoff, 1996; Dyer, 1997; Dyer, 1998) demonstrates that some life history characteristics may be subject to phylogenetic constraints and should be further studied to ascertain their usefulness in systematics.

Research on life-history patterns by comparing several species or groups of species for which phylogenetic hypotheses are available, can contribute to a better understanding of the relative roles of environmental conditions and phylogeny in the life history of silversides, with implications for conservation and management.

Acknowledgments - The authors are grateful to C. B. Fialho, L. Beheregaray, L. R. Malabarba, and S. M. Hartz for their contribution to this work; to the several colleagues that helped in field and laboratory; and to the Centro de Ecologia/UFRGS for logistic support. Financial support was provided by CNPq (Conselho Nacional de Desenvolvimento Científico e Tecnológico), the Brazilian governmental agency for scientific and technological development (research grant to F.G. Becker, proc. 464545/00-5), and FAPERGS (proc. 91.01276.0).

\section{REFERENCES}

AGUILAR, J. F. \& NAVARRETE, N., 1997, Crescimiento, condición y mortalidad del charal Chirostoma humboldtianum (Atheriniformes: Atherinidae) em México. Rev. Biol. Trop., 44/45: 573-578.

BAGENAL, T. B. \& TESCH, F. W., 1978, Age and growth, pp. 101-136. In: T. B. Bagenal (ed.), Methods for assessment of fish production in fresh waters. Blackwell Scientific Publications, Oxford, UK, 365p.

BAMBER, R. N. \& HENDERSON, P. A., 1988, Pre-adaptive plasticity in atherinids and the estuarine seat of teleost evolution. J. Fish Biol., 33(suppl. A): 17-23.

BARBOUR, C. D., 1973, A biogeographical history of Chirostoma (Pisces: Atherinidae): a species flock from the Mexican Plateau. Copeia, 1973: 533-556.

BECKER, F. G., 1995, Dinâmica de reprodução, alimentação e crescimento de três espécies de peixe-rei (Odontesthes), em lagoas costeiras do litoral norte do Rio Grande do Sul (Pisces, Atheriniformes). Dissertação de Mestrado, Universidade Federal do Rio Grande do Sul, Porto Alegre, Brasil, 149p.

BEHEREGARAY, L. B., 2000, Molecular evolution, biogeography and speciation of the Neotropical fish genus Odontesthes. Ph.D. thesis, Macquarie University, Australia. 216p.

BEHEREGARAY, L. B. \& LEVY, J. A., 2000, Population genetics of the silverside Odontesthes argentinensis (Teleostei, Atherinopsidae): evidence for speciation in a estuary of southern Brazil. Copeia, 2000: 441-447. 
BEHEREGARAY, L. B. \& SUNNUCKS, P., 2000, Microsatellite loci isolated from Odontesthes argentinensis and the $O$. perugiae species group and their use in other South American silverside fish. Mol. Ecol., 9: 629-644.

BEHEREGARAY, L. B., SUNNUCKS, P. \& BRISCOE, D., 2002, A rapid fish radiation associated with the last sea level changes in southern Brazil: the silverside Odontesthes perugiae complex. Proc. R. Soc. Lond. B., 269: 65-73.

BEMVENUTI, M. A., 1987, Abundância, distribuição e reprodução de peixes-rei (Atherinidae) na região estuarina da lagoa dos Patos, RS, Brasil. Atlântica, 9: 5-32.

BEMVENUTI, M. A., 1993, Redescrição do peixe-rei Odontesthes argentinensis (Valenciennes) Pisces: Atherinidae, na costa do Rio Grande do Sul. Atlântica, 15: 17-35.

BEMVENUTI, M. A., 1997, Relações morfológicas e osteológicas entre Odontesthes perugiae e Odontesthes mirinensis (Teleostei: Atherinidae: Atherinopsinae). Atlântica, 19: 113-131.

BURBIDGE, R. G., CARRASCO, M. C. \& BROWN, P. A., 1974, Growth, length-weight relationship, sex ratio and food habits of the Argentine pejerrey, Odonthestes bonariensis, from Lake Peñuelas, Valparaíso, Chile. J. Fish Biol., 6: 299-305.

CAMPANA, S. E., 2001, Accuracy, precision and quality control in age determination, including a review of the use and abuse of age validation methods. J. Fish Biol., 59: 197-242.

CIECHOMSKI, J. D., 1972, Reproducción y fecundidad del cornalito Austroatherina incisa (Jenyns, 1942) Maureuo, 1950. Pisces, Atherinidae. Anales Soc. Cient. Argent., 193: 263-272.

CONAND, F., 1993, Life history of the silverside Atherinomprus lacunosus (Atherinidae) in New Caledonia. J. Fish Biol., 42: 851-863.

CONOVER, D. O., 1985, Field and laboratory assessment of patterns in fecundity of a multiple spawning fish: the Atlantic silverside Menidia menidia. Fish. Bull., 88: 331-341.

CREECH, S., 1991, An electrophoretic investigation of populations of Atherina boyeri Risso, 1810 and Atherina presbyter Cuvier, 1829 (Teleostei, Atherinidae): genetic evidence in support of the two species. J. Fish Biol., 39: 807-816.

CREECH, S., 1992a, A multivariate morphometric investigation of Atherina boyeri Risso, 1810 and Atherina presbyter Cuvier, 1829 (Teleostei: Atherinidae): morphometric evidence in support of the two species. J. Fish Biol., 41: 341-353.

CREECH, S., 1992b, A study of the population biology of Atherina boyeri Risso, 1810 in Aberthaw Lagoon, on the Bristol Channel, in South Wales. J. Fish Biol., 41: 277-286.

DINGERKUS, G. \& UHLER, L. D., 1977, Enzyme clearing of alcian blue stained whole small vertebrates for demonstration of cartilage. Stain Technology, 52: 229-232.

DYER, B. S. \& CHERNOFF, B., 1996, Phylogenetic relationships among atheriniform fishes (Teleostei: Atherinomorpha). Zool. J. Linn. Soc., 117: 1-69.

DYER, B. S., 1997, Phylogenetic revision of Atherinopsinae (Teleostei, Atherinopsidae), with comments on the systematics of the South American freshwater fish genus Basilichthys Girard. Misc. Publ. Mus. Zool. Univ. Michigan, 185: 1-64.

DYER, B. S., 1998, Phylogenetic systematics and historical biogeography of the Neotropical silverside family Atherinopsidae (Teleostei: Atheriniformes), pp. 519-536. In: L. R. Malabarba, R. E. Reis, R. P. Vari, Z. M. Lucena \& C. A. S. Lucena (eds.), Phylogeny and classification of neotropical fishes. EDIPUCRS, Porto Alegre, Brazil, 603p.
ELÍAS, I., RÉ, M. E. \& GOSZTONYI, A. E., 1991, Observaciones preliminares sobre el crescimiento del Pejerrey "Manila" Odontesthes smitti: (Atherinidae) en el Golfo Nuevo, Chubut, Argentina. Rev. Biol. Mar., 26: 49-60.

FERNANDEZ-DELGADO, C., HERNANDO, J. A., HERRERA, M. \& BELLIDO, M., 1988, Life-history patterns of the sandsmelt Atherina boyeri Risso, 1810 in the estuary of the Guadalquivir River, Spain. Estuar. Coast. Shelf. Sci., 27: 697-706.

FIALHO, C. B. \& VERANI, J. R., 1994, Dinâmica da alimentação de Odontesthes aff. perugiae (Evermann \& Kendall, 1906) da Lagoa Emboaba, RS, Brasil. (Atheriniformes, Atherinidae). Comunicações do Museu de Ciências e Tecnologia da PUCRS, 7: 29-40.

FIALHO, C. B., 1996, Biologia de Odontesthes aff. perugiae (Evermann \& Kendall,1906) da Lagoa Emboaba. Boletim do Instituto de Biociências UFRGS, 55: 59-68.

FIALHO, C. B., VERANI, J. R., PERET, A. C. \& BRUSCHI, W. Jr., 1996, Dinâmica da reprodução de Odontesthes aff. perugiae (Evermann \& Kendall, 1906) da lagoa Emboaba, RS, Brasil (Pisces, Atherinidae). Boletim do Instituto de Pesca, São Paulo, 23: 105-115.

FIALHO, C. B., 1992, Dinâmica do crescimento, reprodução e alimentação de Odontesthes aff. perugiae (Evermann \& Kendall, 1906) da lagoa Emboaba, Osório, RS, (Atheriniformes, Atherinidae). Dissertação de Mestrado, Universidade Federal do Rio Grande do Sul, Porto Alegre, Brasil, 138p.

FREYRE, L., 1976, La población de pejerrey de la Laguna de Lobos. Limnobios, 1: 105-128.

GAJARDO, G. M., 1987, Basilichthys microlepidotus (Jenyns, 1842) and Basilichthys australis Eingenman, 1927 (Pisces: Teleostei: Atherinidae): comments on their morphological differentiation. Stud. Neotrop. Fauna. Environ., 22: 223-236.

GAJARDO, G. M., 1988, Genetic divergence and speciation in Basilichthys microlepidotus Jenyns, 1842 and Basilichthys australis Eigenmann, 1927 (Pisces, Atherinidae). Genetica, 76: $121-126$.

GAJARDO, G. M., 1992, Karyotypes of Basilichthys microlepidotus and B. australis (Pisces: Atherinidae). Copeia, 1992: 256-258.

GALLEGO, L., LINDE, M. \& BEMVENUTI, M. A., 1998, Aplicación práctica del uso de una función de clasificación para determinar especies del género Odontesthes (Osteichthyes, Atherinidae). Bol. R. Soc. Esp. Hist. Nat., 94: 105-111.

GOULD, S. J., 1966, Allometry and size in ontogeny and phylogeny. Biol. Rev. Camb. Philos. Soc., 41: 587-640.

HUBBS, C., 1982, Life history dynamics of Menidia beryllina from Lake Takoma. Am. Midl. Nat., 107: 1-12.

JIMENEZ-BADILLO, M. D. L. \& GRACIA, G. A., 1995, Assessment of the multispecific fishery of Chirostoma spp. (Pisces, Atherinidae) of Lago de Patzucaro, Michoacan, Mexico. An. Inst. Biol. Univ. Nac. Auton. Mexico, Serie Zool., 66: 205-231.

KLINK, A. \& ECKMANN, R., 1985, Age and growth, feeding habits and reproduction of Cauque mauleanum Steindachaer 1986 (Pisces: Atherinidae) in Southern Chile. Stud. Neotrop. Fauna Environ., 20: 239-249.

LAHILLE, F., 1929, El pejerrey. Boletin del Ministerio de Agricultura, Buenos Aires, 28: 261-395. 
LE CREN, E. D., 1951, The length-weight relationship and seasonal cycle in gonad weight and condition in the perch Perca fluvialitis. J. Anim. Ecol., 20: 201-219.

LEONARDOS, I. \& SINIS, A., 2000, Age, growth and mortality of Atherina boyeri Risso, 1810 (Pisces: Atherinidae) in the Mesolongi and Etolikon lagoons (W-Greece). Fish. Res., 45: 81-91.

LOWE-McCONNEL, R. H., 1987, Ecological studies in tropical fish communities. Cambridge University Press, Cambridge, UK, 382p.

MALABARBA, L. R. \& DYER, B, 2002, Description of three new species of the genus Odontesthes from the rio Tramandaí drainage, Brazil (Atheriniformes: Atherinopsidae). Ichthyol. Explor. Freshwaters, 13(3): 257-272.

MARKEVICH, N. B., 1977, Some morphophysiological indices of the silverside, Atherina mochon pontica, in the Aral Sea in connection with the age structure of the population. $J$. Ichthyol., 17: 618-626.

MILES, D. B. \& DUNHAM, A. E., 1993, Historical perspectives in ecology and evolutionary biology: the use of phylogenetic comparative analysis. Ann. Rev. Ecol. Syst., 23: 587-619.

MILTON, D. A. \& ARTHINGTON, A. H., 1983, Reproduction and growth of Craterocephalus marjorie and $C$. stercusnuscarum (Pisces: Atherinidae) in south-eastern Queensland, Australia. Freshwat. Biol., 14: 585-597.

MORENO, C. A., URZÚA, R. \& BAHAMONDE, N., 1977, Breeding season, sexual rate and fecundity of Basilichthys australis Eigenmann 1927, from Maipo River, Chile. (Atherinidae, Pisces). Stud. Neotrop. Fauna Environ., 12: 217-223.

NIKLOSKY, G. V., 1963, The ecology of fishes. Academic Press, London, UK, 352p.

PAIVA FILHO, A. M. \& GIANNINI, R., 1990, Contribuição ao conhecimento da biologia do peixe-rei, Xenomelaniris brasiliensis (Quay \& Gaimard, 1821) (Atherinidae), no complexo baía-estuário de Santos e São Vicente, Brasil. Bolm. Inst. Oceanogr. S. Paulo, 38: 1-9.

PALMER, C. J. \& CULLEY, M. B., 1983, Aspects of the biology of the sandsmelt Atherina boyeri Risso, 1810 (Teleostei: Atherinidae) at Old bury-upon-Severn, Gloucestershire, England. Estuar. Coast. Shelf. Sci., 16: 163-172.

POTTER, I. C., IVANTSOFF, W., CAMERON, R. \& MINNARD, J., 1986, Life cycles and distribution of atherinids in the marine and estuarine waters of southern Australia. Hydrobiologia, 139: 23-40.

PRINCE, J. D. \& POTTER, I. C., 1983, Life cycle duration, growth and spawning times of five species of Atherinidae (Teleostei) found in a Western Australian Estuary. Aust. J. Mar. Freshwat. Res., 34: 287-301.

PRODOHL, P. A. \& LEVY, J. A., 1989, Genetic study of Atherinidae fishes of Mangueira Lagoon (Rio Grande do Sul, Brazil). Comp. Biochem. Physiol. B, 94: 423-426.

RICKER, W. E., 1975, Computation and interpretation of biological statistics of fish populations. Bull. Fish. Res. B. Can., 191: 1-382.

SANTOS, E. P., 1978, Dinâmica de populações aplicada à pesca e piscicultura. Hucitec e Ed. Universidade de São Paulo, São Paulo, Brasil, 129p.
SCASSO, F. \& CAMPOS, H., 1999, Comparison of two populations of Silverside, Odontesthes bonariensis (Pisces, Atherinopsidae) in eutrophied lakes from central Chile. $J$. Freshwat. Ecol., 14: 61-70.

SCHWARZBOLD, A. \& SCHÄFER, A., 1984, Gênese e morfologia das lagoas costeiras do Rio Grande do Sul, Brasil. Amazoniana, 9: 87-104.

SVERLIJ, S. B. \& ARCEREDILLO, J. P. M., 1991, Growth of the Argentine silverside, Odontesthes bonariensis, Pisces, Atheriniformes, in La Florida Reservoir (San Luis, Argentina). Rev. d'Hydrobiol. Trop., 24: 183-196.

SWEET, S. S., 1980, Allometric inference in morphology. Am. Zool., 20: 643-652.

TURNPENNY, A. W. H., BAMBER, R. N. \& HENDERSON, P. A., 1981, Biology of the sand-swelt (Atherina presbyter Vallencienes) around Fawley power station. J. Fish Biol., 18: 417-427.

UNGER, P. A. \& LEWIS, W., 1991, Population ecology of a pelagic fish, Xenomelaniris venezuelae (Atherinidae), in lake Valencia, Venezuela. Ecology, 72: 440-456.

VAZZOLER, A. E. A. M., 1981, Manual de métodos para estudos biológicos de populações de peixes: reprodução e crescimento. $\mathrm{CNPq}$, Brasília, Brasil, 108p.

VAZZOLER, A. E. A. M., LIZAMA, M. L. A. P. \& INADA, P., 1997, Influências ambientais sobre sazonalidade reprodutiva, pp. 267-280. In: A. E. A. de M. Vazzoler, A. A. Agostinho \& N. S. Hahn (eds.), A planície de inundação do Alto Rio Paraná. EDUEM-Nupélia, Maringá, Brasil, 460p.

VILA, I. \& SOTO, D., 1986, Odontestes bonariensis pejerrey argentino, uma especie para cultivo extensivo, pp. 224-228. In: I. Vila \& F. Fagetti (eds.), Taller internacional sobre ecología y manejos de peces en lagos y embalses. COPESCAL, Doc. Téc. n. 4, Chile, 237p.

VILA, I., SOTO, B. D. \& BAHAMONDES, I., 1981, Age and growth of Basilichthys australis Eigenmannn, 1927, in Rapel Reservoir, Chile. (Pisces, Atherinidae). Stud. Neotrop. Fauna Environ., 16: 9-22.

VILLAVICENCIO, Z. \& MUCK, P., 1984, Estudio de otolitos de Odontesthes regia r., pejerrey: determinación de edad. Bol. Inst. Mar. Peru, 8: 73-100.

WARKENTINE, B. E. \& RACHLIN, J. W., 1987, Age and growth of 0+ year class Menidia menidia. Ann. New York Acad. Sci., 494: 438-440.

WEBB, P. W., 1984, Body form, locomotion and foraging in aquatic vertebrates. Amer. Zool., 24: 107-120.

WILHELM, W., 1984, Interspecific allometric growth differences in the head of three haplochromine species (Pisces, Cichlidae). Neth. J. Zool., 34: 622-628.

WOOTTON, R. J., 1990, Ecology of teleost fishes. Chapman \& Hall, London, 404p.

ZAR, J. H., 1999, Biostatistical analysis. Prentice-Hall, Upper Saddle River, $4^{\text {th }}$ ed., $663 \mathrm{p}$. 